\title{
Criteria for Site Selection of Solar Parks in Bangladesh: A Delphi-AHP Analysis
}

\author{
Md. T. Rahman ${ }^{1 *}$, Mohammad Shakil AKTher $^{2}$ \\ AND SOUMITRO K. SARKER ${ }^{2}$ \\ ${ }^{1}$ Dhaka Water Supply Network Improvement Project (DWSNIP), \\ Dhaka Water Supply and Sewerage Authority, Bangladesh \\ ${ }^{2}$ Bangladesh University of Engineering and Technology, Bangladesh
}

\begin{abstract}
The demand for electricity is increasing fast in Bangladesh to sustain rapid economic growth. The largest share of electricity in Bangladesh is produced by fossil fuel powered electricity generation plants. Though solar energy has high potential in Bangladesh due to favorable geographical location, very little initiative has been taken to develop the solar energy sector. At present, the Bangladesh government's approval criteria for site selection of solar energy parks does not have any scientific basis. Consequently, the present study was undertaken to develop the site selection criteria for solar parks in Bangladesh. Delphi method with AHP was used to determine the criteria and its weightage for site selection of solar energy park. Two rounds of questionnaire for the Delphi method were conducted: in the first, the criteria list was formulated, and in the second, the weightage of the criteria was finalized. The finalized criteria were: land cover (i.e., vegetation, water bodies, build up area, bare land), land slope, surface solar irradiance, land surface temperature, and location of power sub-stations. Among these, land cover and location of power sub-stations were found to have the highest significance for determining suitable locations for solar energy parks in regard to Bangladesh.
\end{abstract}

Keywords: solar energy parks, site selection criteria, Analytical Hierarchy Process, Delphi method

\section{INTRODUCTION}

Energy is one of the key elements for the prosperity of a society. Access to affordable, reliable, sustainable, and modern energy for all is set as one of the goals for sustainable development by UN [1]. There is consensus that renewable energy is sustainable, clean, and free or low cost [2]. However, still more than $80 \%$ of world energy comes from non-renewable resources [3].

Bangladesh is consistently maintaining an annual GDP growth rate over five since 2004 [4]. As researches over the years regularly show that there is a positive relationship between economic

*Corresponding author: touhidur002@gmail.com

Received: 5 Oct 2020 Accepted: 15 Oct 2020 Published: 28 Oct 2020

Journal of Asian Energy Studies (2020), Vol 4, 26-35, doi:10.24112/jaes.040004 
growth and electricity consumption [5-9], the demand for electricity has also increased (Figure 1). Bangladesh produces almost all of its electricity by burning fossil fuels [10]. At present, the main source of electricity is natural gas (48.81\% of total production) [10]. Government has to import a huge quantity of oil for producing electricity [11]. In addition, the fossil fuel-based electricity plants also emit greenhouse gases (GHG) that negatively affect the environment. Bangladesh has already committed to reduce its GHG emissions to 5\% below the Business as Usual Scenario or 12 Metric Ton of CO2 by 2030 in power, industry, and transport sector by 2030 unconditionally [12].

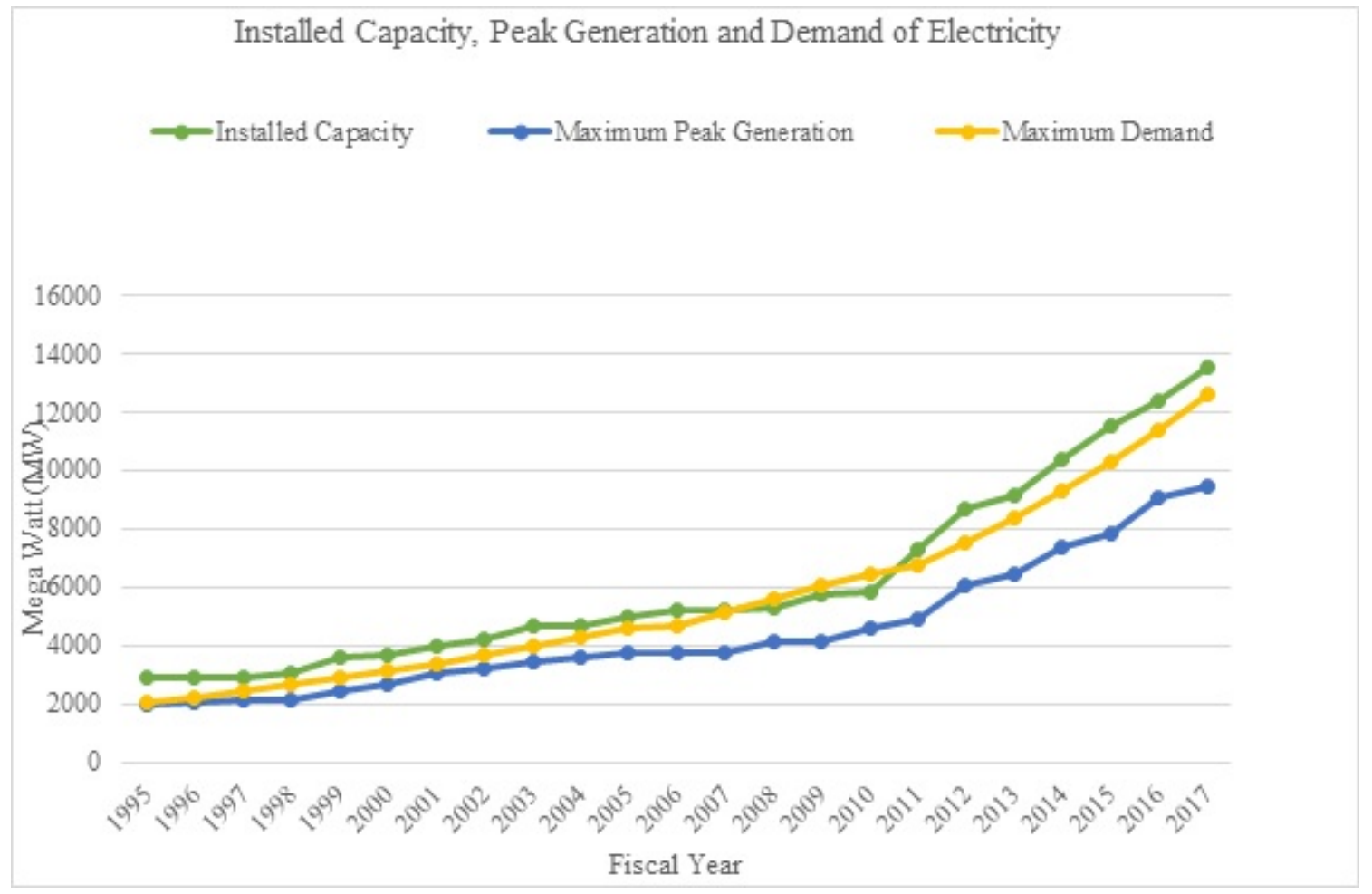

Figure 1: Demand for electricity over the time period 1995 to 2017 (Source: [17])

Due to increased concern for environment all over the world, renewable energy has become the desired source for energy. In fact, UN urged that a substantial share of energy would come from renewable source by 2030 [1]. Many countries of the world are in fact increasingly producing a large share of their electricity from renewable sources. For example, in Denmark, the share of renewable energy consumption increased from a meager $7.02 \%$ in 1990 to $33.17 \%$ in 2015 [13]. However, in Bangladesh, the share of renewable energy consumption decreased from $71.66 \%$ to $34.74 \%$ in the same period [14]. Even as one considers renewable energy for electricity production, with the world's share increasing from 19.36\% in 1990 to $22.85 \%$ in 2015 [15], Bangladesh's share decreased from $11.43 \%$ to $1.23 \%$ [16].

Realizing this, the government is now encouraging investors to develop electricity plant based on renewable energy [17]. However, the options are very limited. There is very little scope for hydropower [18]. Although high wind speed prevails in the southern coastal belt of Bangladesh, the frequent cyclones in these areas make it unrealistic to have a wind park [19]. In such circumstances, solar energy could be one of the major sources for renewable energy for electricity production. The geographical location of Bangladesh makes it very suitable to exploit 
solar energy as the country receives 300 clear sunny days per year; which is enough to produce an enormous amount of solar energy in a sustainable way [20]. In addition, solar energy is considered as one of the areas of National Area of Mitigation Action (NAMA) to meet the commitment of reducing GHG emission [21].

Considering this, Bangladesh has undertaken projects based on solar energy to produce electricity. The government is encouraging private sector investment in developing solar energy parks in different parts of the country. However, the criteria set for setting up a solar energy park are more bureaucratic than scientific. According to the Sustainable and Renewable Energy Development Authority (SREDA) [10], if an investor meets any of the following criteria, (s)he could set up a solar energy park:

- Government owned non-agricultural land; and

- Private land owned by individual people

It could be understood from the above criteria that the sites thus selected may not be in suitable locations. Discussions with SREDA officials responsible for granting permission and implementation of renewable energy projects reveal that at the moment they are not thinking about developing any other criteria for setting up solar parks. As setting up of a solar energy park is a multi-million-dollar investment [22], the site selection for it should be based on scientific criteria. It is in light of these rationales that this research has been undertaken to develop criteria for site selection for solar energy park.

\section{Materials ANd Methods}

\subsection{Literature Review}

Criteria for site selection of solar energy parks vary across countries depending on the country's geographical and physical conditions [?]. As the decision of locating a solar-powered electricity generation plant site has a strong relationship with the plant's security, it has to meet the meteorological, economical, environmental, and societal requirements [24,25]. The locations with the highest solar resources are not always feasible sites for solar energy parks; as variety of factors play a role in the site selection process of solar farms [26]. Hence, site selection of solar power system has become difficult for the electricity generation enterprises, grid enterprises, and government [24]. Thus, different criteria were used for setting up solar energy parks in different countries of the world.

Radiations, leveled unit cost of electricity, emission reduction constraint, and environmental factors have been considered in India for site selection of solar parks [27-29]. Ribeiro et al. found that the size and shape of land as well as distance from power grids could make significant variations in power generation in Brazil [30]. Uyan took into account quality of terrain, local weathering factors, proximity to high transmission capacity lines, agricultural facilities, and environmental conservation issues for optimum site selection in Turkey [24]. Kereush and Perovych acknowledged social, geographical, technological, and environmental factors (for example: average air temperatures, abundant solar radiation, and protected areas) play key roles in setting up solar energy parks in Ukraine [31]. Beltran et al. mentioned project execution delay and stoppage risk as crucial factors for site selection of solar parks in Spain [32]. Francois et al. used standard deviation of energy balance and storage requirement as determining factors in Italy [33]. On the other hand, Carrion et al. emphasized on environmental, geographical, location, and climate factors as crucial in site selection for solar energy parks in the European Union [34]. Broesamle et al. developed an evaluation system for solar thermal power stations, which was designed to calculate 
the performance of such power stations as a function of direct solar radiation, geographical conditions (land slope, land cover, distance from power stations, etc.), and infrastructure (pipelines, electricity grids, streets etc.) [35]. In order to demonstrate the concept, they performed an analysis of Northern Africa; where sites were ranked according to solar power potential. On the other hand, Gasti and Charabi focused on geographic and topographic conditions of Oman to assess its solar power prospect [36].

The combination of Delphi and AHP technique has been increasingly used to solve multicriteria decision-making problems. AHP is a widely used method for analyzing and supporting decisions, which have multiple and even competing objectives [37,38]. Since its introduction in 1977 [39], AHP has been widely used for various purposes including but not limited to selection and evaluation of criteria in different kind of sectors like healthcare [40], manufacturing [41], project selection and resource allocation [42], machine and automobile selection, [43,44] etc. Delphi is a structured, systematic, and interactive method used to gain consensus of experts on a particular topic through a series of questionnaires (usually two or more) [45-50]. AHP in combination with Delphi method is widely used for selecting criteria for different purposes. For example, Wood had used this combination to identify the key success factors in strategic alignment of transport collaboration [51]. He first used Delphi method to identify and quantify relevant criteria, and then used AHP approach to estimate the relative importance of the extracted criteria. Kazemi et al. have used an indistinct Delphi-AHP method to investigate and evaluate critical material selection criteria in a priority framework in order to choose the most appropriate materials for any design [52]. Vidal et al. have used Delphi process with incorporation of AHP to evaluate the complexity of projects [53]. Kharat et al. have used Delphi-AHP method for selecting criteria for environmentally conscious solid waste treatment and disposal technology [54]. Kwok and Lau in their research used this method to gather experts' opinions on the evaluation criteria and their relative importance for selecting a suitable road junction control method in a multiobjective environment [55]. On the other hand, Sadr used the method to identify potential sites for ecotourism [56]. Colak and Kaya used the methods to evaluate energy storage technologies [57]. Interestingly, Akbar et al. even used the AHP-Delphi combination to rank root causes of marine accident [58].

\subsection{Selection and Finalization of Criteria}

As both Delphi method and AHP consider the opinions of expert, the researchers tried to make a list of solar energy experts who are working in Bangladesh. It should be noted here that there are very few such scholars in the country. Six experts with considerable experience, both from academia and practice, were chosen and gave their consent to answer the queries of the researchers.

For selecting and identifying criteria weightage, two rounds of questionnaire survey were conducted among the experts. In the first round, the experts were asked to comment on the primarily selected criteria, and when they reached a consensus on it, round one was deemed to be completed. In the second round, the experts were asked to compare the selected criteria on pairwise basis using Saaty Scale [59].

As the criteria for site selection vary from country to country, it was decided to use experts' opinion to identify if there are any other specific criteria for Bangladesh. Based on literature review $[29,31,32,36]$, the following criteria were initially selected for first round of Delphi questionnaire.

- Surface Solar Irradiance (SSI)

- Land Surface Temperature (LST)

- Land Slope (LS) 
- Land Cover

- Location of Power Sub-stations

It should be mentioned here that there were options for the experts for addition and deletion of any criteria.

\subsection{Implementing AHP}

After the experts' pairwise comparison of the selected criteria, the AHP procedure was implemented to determine the relative weights of the criteria. It was done through

- Computing the vector of criteria weights

- Computing the matrix of option scores

- Ranking the options

Not all the criteria will have the same importance. Therefore, it is essential to derive the relative priorities (weights) for the criteria. In order to compute the weights for the different criteria, AHP was used. In AHP, a pairwise matrix is developed with relative importance between two criteria according to a numerical scale from 1 to 9 which was developed by Saaty [59]. The value is then normalized to determine the weight of each criterion.

It is necessary to look at whether there is inconsistency in the valuation of weightage by experts. It could be determined by using Consistency Ratio (CR). Saaty claimed that a CR of 0.10 or less is acceptable to continue the AHP analysis [59]. If the consistency ratio is greater than 0.10 , it is necessary to revise the judgments to locate the cause of the inconsistency and correct it. However, there are literatures [60-62] which suggest that depending upon the number of experts and number of criteria, even a CR value of 0.2 is acceptable. If $C R$ value weightage of any expert crosses the threshold value (i.e. CR value more than 0.1 ), his (her) weightage of the criteria is discarded, and the final criteria weightage is calculated on average weightage value of the experts whose CR is below the threshold value.

\section{Results ANd Discussion}

As mentioned in the previous section, the researchers worked with six experts to determine the criteria and their weightage for selecting solar energy park sites in Bangladesh. After the first round of survey, the experts agreed on the following criteria:

- Surface Solar Irradiance (SSI)

- Land Surface Temperature (LST)

- Land Slope (LS)

- Land Cover

- Location of Power Sub-stations

Incidentally these were the very criteria the researchers choose as the initial set. Though experts also suggested for cloud index, suitable land shape, amount of dust in dry season, and cost of land as criteria, they could not reach consensus on those criteria.

In the second round, the researchers provided weightage for each of the criteria. However, during calculation of $\mathrm{CR}$, it was found that the weightage of one of the experts was inconsistent (i.e. the $C R$ value was higher than the threshold value of 0.1 , even 0.2 ). So, the weightage was calculated (Table 1) ignoring the weightage value whose CR value was found to be higher than the threshold value. 
Journal of Asian Energy Studies (2020), Vol. 4, 26-35

Table 1: Final weightage of the criteria

\begin{tabular}{lcccccc}
\hline Criteria & Expert & Expert & Expert & Expert & Expert & Final \\
& 1 & 2 & 3 & 4 & 5 & Weightage \\
\hline Surface Solar Irradiance & 0.116 & 0.044 & 0.087 & 0.301 & 0.121 & 0.134 \\
Land Surface Temperature & 0.091 & 0.046 & 0.046 & 0.283 & 0.034 & 0.100 \\
Land Slope & 0.037 & 0.095 & 0.062 & 0.074 & 0.083 & 0.070 \\
Land Cover & 0.350 & 0.547 & 0.412 & 0.042 & 0.389 & 0.348 \\
Location of Power & 0.406 & 0.267 & 0.392 & 0.301 & 0.372 & 0.348 \\
Sub-stations & & & & & & \\
\hline
\end{tabular}

*Please note that continuity of numbers was considered in numbering the expert; it no way indicates that the opinion of Expert no 6 is ignored rather it indicates that opinion of one of the experts were not considered.

From the table, it can be seen that Land Cover and Location of Power Sub-stations are the top two priorities among the five criteria to all experts, except Expert no 4 who considered surface solar irradiance over land cover. The other experts, except Expert 1, have considered land cover more important than other criteria. But the weightage difference between land cover and location of power grid is meager, hence, once the weightage of Expert no 4 is considered; land cover and location of power grid have got equal importance.

Barren land is most suitable for big solar projects, as there is a severe land scarcity in Bangladesh. According to experts, a thumb rule is that, with the current available technology, $120 \mathrm{KW}$ electricity can be generated from one Bigha (One Bigha is equal to 17,424 square foot). This is the largest unit of a real measurement in local system of land, provided proper maintenance is done. Experts have discouraged the conversion of agricultural land for usage in solar power projects. On the other hand, they restricted the use of built-up and forest areas for such projects. High capacity grid lines in close proximity to the solar project site is important because if the selected site is located far from grid lines, new power sub-stations need to be constructed; which will increase the project cost and therefore, will reduce the viability of the project.

The third important criterion was SSI, which bears a weight of $13.4 \%$. The least important ones are LST and LS; bearing a weight of $10 \%$ and $7 \%$, respectively. According to the experts, LST is quite same for Bangladesh. Therefore, it does not have much effect on site selection. Again, LS can be dealt by varying the height of the frame.

\section{Conclusion}

A reliable, affordable, and secure supply of energy is important for socio-economic development. As a country with decreasing share of renewable energy in total energy consumption and production $[14,16]$, Bangladesh is now looking forward to develop its renewable energy sources in addition to its traditional source of fossil fuel. Studies [18,63-66] suggest that Bangladesh has good potential for harnessing solar energy due to her geographical and physical characteristics; realizing this, the government of the country is now focusing on establishing solar energy parks.

The study puts high importance on land cover and location of power sub-stations (both have a weightage of $34.8 \%$ ) in order to determine suitable sites for solar energy parks. Uyan has advised the same in his study in Turkey; where he has calculated the weightage of land cover and distance from transmission lines respectively as $41.25 \%$ and $37.4 \%$ [24]. Broesamle et al. have also given high priority to land cover as they have suggested considering surface water, forests, settlements, 
arable, and cultivated land as unsuitable for establishing solar plants [35]. Both Broesamle et al. and Gasti \& Charabi have put the highest importance on SSI which has been found as the third most important factor in this study [35,36]. As Bangladesh has a small geographical extent, SSI does not vary significantly in Bangladesh (from 4 to $6.5 \mathrm{kWh} / \mathrm{m} 2$ in the whole country) [63]. Therefore, big parcels of vacant land (land cover), which are scarce in Bangladesh, have greater weightage than SSI. Land slope only carries a meager $7 \%$ weightage in determining suitable sites for solar plants, which contradicts that of Gasti \& Charabi who have put great importance on LS in their study to assess solar electricity prospects in Oman [36]. One of the reasons behind this contradiction may be the topography of Bangladesh is flat with the exception in the south-east and north-east where there are the hilly areas [67]. But it should be mentioned here that, the calculated weightage of LS in this study nearly matches that of Uyan, who has estimated the weightage of land slope for Turkey is approximately $8 \%$ [24]. Therefore, LS does not carry significant importance for Bangladesh in determining suitable sites for solar energy parks.

For proper utilization of the solar power potential of Bangladesh [20] with limited land for development of solar energy parks, the parks should be located in the most suitable places to ensure maximum effectiveness. However, the government presently has no evaluation system based on which suitable sites for solar energy parks can be determined. This study developed the criteria applicable in case of Bangladesh for the selection of suitable sites for solar energy parks. Since the study has proposed the name and priority of criteria from renowned experts and regulatory bodies, it can be used as a base for site selection of solar parks.

\section{REFERENCES}

[1] UN. About the Sustainable Development Goals. 2020. Available: https://www.un.org/sustainabledevelopment/sustainable-development-goals/

[2] Urmee T, Harries D, Schlapfer A. Issues related to Rural Electrification using Renewable Energy in Developing Countries of Asia and Pacific. Renewable Energy 2009:34:354-357.

[3] BP. BP Statistica Review of World Energy. 2018.

[4] World Bank. GDP growth (annual \%) - Bangladesh. 2020. Available: https://data.worldbank.org/indicator/NY.GDP.MKTP.KD.ZG?locations=BD

[5] Dogan E. The Relationship between Economic Growth and Electricity Consumption from Renewable and Non-renewable Sources: A study of Turkey. Renewable and Sustainable Energy Reviews 2015:52:534-546.

[6] Kasperowicz R. Electricity consumption and economic growth: Evidence from Poland. Journal of International Studies 2014:7:46-57.

[7] Abbas F, Choudhury N. Electricity consumption economic growth nexus: An aggregated and disaggregated causality analysis in India and Pakistan Journal of Policy Modeling 2013:35:538-553.

[8] Masuduzzaman M. Electricity consumption and economic growth in Bangladesh: Co-integration and causality Ministry of Fianace, Bangladesh, Dhaka. 2012.

[9] Yoo SH. The causal relationship between electricity consumption and economic growth in the ASEAN countries. Energy Policy 2006:34:3573-3582.

[10] SREDA. National Database of Renewable Energy. 2020. Available: http:/ / www.renewableenergy.gov.bd/index.php?id=7

[11] Rasel AR. Govt allows 5 Private Power Plants to Import Fuel Oil. Dhaka Tribune. 2017. Available: http:/ / www.dhakatribune.com/bangladesh/power-energy/2017/08/13/govt-allows-5private-power-plants-import-fuel-oil/ 
[12] Ministry of Environment, Forest and Climate Change (MoEFCC). Nationally Determined Contribution of Bangladesh. Government of Bangladesh, Dhaka, 2015.

[13] World Bank. Renewable energy consumption (\% of total final energy consumption) - Denmark. 2020. Available: https:/ /data.worldbank.org/indicator/EG.FEC.RNEW.ZS?end=2015\&locations= DK\&start $=1990 \&$ view $=$ chart

[14] World Bank. Renewable energy consumption (\% of total final energy consumption) - Bangladesh 2020. Available: https://data.worldbank.org/indicator/EG.FEC.RNEW.ZS?end=2015\&locations= BD\&start $=1990 \&$ view $=$ chart

[15] World Bank. Renewable electricity output (\% of total electricity output). 2020. Available: https://data.worldbank.org/indicator/EG.ELC.RNEW.ZS

[16] World Bank. Renewable electricity output (\% of total electricity output) - Bangladesh. 2020. Available: https://data.worldbank.org/indicator/EG.ELC.RNEW.ZS?locations=BD

[17] Bangladesh Power Development Board. Annual Report 2016-2017. Bangladesh Power Development Board, Dhaka, 2018.

[18] Hossain AK, Badr O. Prospects of renewable energy utilisation for electricity generation in Bangladesh. Renewable and Sustainable Energy Reviews 2007:11:1617-1649.

[19] Sarker MAR, Ehsan M, Islam MA. Issues relating to energy conservation and renewable energy in Bangladesh. Energy for Sustainable Development 2003:7:77-87.

[20] Hasan F, Hossain J, Rahman M, Sazzad A. Design and Development of a Cost Effective Urban Residential Solar PV System. Bangladesh University of Engineering and Technology, 2010.

[21] Ministry of Environment, Forest and Climate Change (MoEFCC). Nationally Determined Contribution of Banglades: Implementation Road Map. Government of Bangladesh, Dhaka, 2017.

[22] Marsh J. Energysage. 2019. Available: https://news.energysage.com/solar-farms-start-one/

[23] Majumder M, Saha AK. Feasibility Model of Solar Energy Plants by ANN and MCDM Techniques. Springer, Singapore, 2016.

[24] Uyan M. GIS-based solar farms site selection using analytic hierarchy process (AHP) in Karapinar region, Konya/Turkey. Renewable and Sustainable Energy Reviews 2013:28:11-17.

[25] Yun-na W, Yi-sheng Y, Tian F, Li-na K, Wei L, Luo-jei F. Macro-site selection of wind/solar hybrid power station based on ideal matter-element model. International Journal of Electrical Power \& Energy Systems 2013:50:76-84.

[26] Van Haaren R, Fthenakis V. GIS-based wind farm site selection using spatial multi-criteria analysis (SMCA): Evaluating the case for New York State. Renewable and Sustainable Energy Reviews 2011:15:3332-3340.

[27] Sharma C, Sharma AK, Mullick SC, Kandpal TC. A study of the effect of design parameters on the performance of linear solar concentrator based thermal power plants in India. Renewable Energy 2016:87:666-675.

[28] Rajesh K, Bhuvanesh A, Kannan S, Thangaraj C. Least cost generation expansion planning with solar power plant using differential evolution algorithm. Renewable Energy 2016:87:677686

[29] Jain A, Mehta R, Mittal SK. Modeling impact of solar radiation on site selection for solar PV power plants in India. International Journal of Green Energy 2011:8:486-498.

[30] Ribeiro AED, Arouca MC, Ceolho DM. Electric energy generation from small-scale solar and wind power in Brazil: The influence of location, area and shape. Renewable Energy 2016:85:554-563.

[31] Kereush D, Perovych I. Determining criteria for optimal site selection for solar power plants. Geomatics, Landmanagement and Landscape 2017:4:39-54. 
[32] Aragones-Beltran P, Chaparro-Gonzalez F, Pastor-Ferrando JP, Rodriguez-Pozo F. An ANP-based approach for the selection of photovoltaic solar power plant investment projects. Renewable and Sustainable Energy Review 2010:14:249-264.

[33] Francois B, Borga M, Creutin JD, Hingray B, Raynaud D, Sauterleute JF. Complementarity between solar and hydro power: Sensitivity study to climate characteristics in Northern-Italy. Renewable Energy 2016:86:543-553.

[34] Carrion JA, Estrella AE, Dols FA, Toro MZ, Rodriguez M, Ridao AR. Environmental decision-support systems for evaluating the carrying capacity of land areas: Optimal site selection for grid-connected photovoltaic power plants. Renewable and Sustainable Energy Reviews 2008:12:2358-2380.

[35] Broesamle H, Mannstein H, Schillings C, Trieb F. Assessment of solar electricity potentials in North Africa based on satellite data and a geographic information system. Solar Energy 2001:70:1-12.

[36] Gastli A, Charabi Y. Solar electricity prospects in Oman using GIS-based solar radiation maps. Renewable and Sustainable Energy Reviews 2010:14:790-797.

[37] Cay T, Uyan M. Evaluation of reallocation criteria in land consolidation studies using the Analytic Hierarchy Process (AHP). Land Use Policy 2013:30:541-548.

[38] Wang G, Qin L, Li G, Chen L. Landfill site selection using spatial information technologies and AHP: a case study in Beijing, China. Journal of Environmental Management 2009:90:2414-2421.

[39] Saaty TL. A scaling method for priorities in hierarchical structures. Journal of Mathematical Psychology 1977:15:234-281.

[40] Schmidt K, Aumann I, Hollander I, Damm K, von der Schulenburg JM. Applying the Analytic Hierarchy Process in healthcare research: A systematic literature review and evaluation of reporting. BMC Medical Informatics and Decision Making 2015:15:112.

[41] Shang J, Sueyoshi T. A unified framework for the selection of a flexible manufacturing system. European Journal of Operational Research 1995:85:297-315.

[42] Liberatore MJ. An extension of the analytic hierarchy process for industrial R\&D project selection and resource allocation. IEEE Transactions on Engineering Management 1987:1:12-18.

[43] Myint S, Tabucanon MT. A multiple-criteria approach to machine selection for flexible manufacturing systems. International Journal of Production Economics 1994:33:121-131.

[44] Byun DH. The AHP approach for selecting an automobile purchase model. Information $\mathcal{E}$ Management 2001:38:289-297.

[45] Hanafin S. Delhi Method: A Literature Review. 2004. Available: https://pdfs.semanticscholar.org/38d8/baf4f555fe5ff230dd75eb8483eb9298cfaa.pdf

[46] Wang CC, Wang Y, Zhang K, Fang J, Liu W, Luo S, Tang S, Wang S, Li VC. Reproductive health indicators for China's rural areas. Social Science \& Medicine 2003:57:217-225.

[47] Rogers MR, Lopez EC. Identifying critical cross-cultural school psychology competencies. Journal of School Psychology 2002:40:115-141.

[48] Linstone HA, Turoff M. The Delphi Method Techniques and Applications. Addison-Wesley, Massachusetts, 1975.

[49] Crisp J, Pelletier D, Duffield C, Adams A, Nagy SU. The Delphi method? Nursing Research 1997:46:116-118.

[50] Sharkey SB, Sharples AY. An approach to consensus building using the Delphi technique: developing a learning resource in mental health. Nurse Education Today 2001:21:398-408.

[51] Wood LC. Contemporary Approaches and Strategies for Applied Logistics. IGI Global, Hershey PA, 2018.

[52] Kazemi S, Homayouni SM, Jahangiri J. A fuzzy delphi-analytical hierarchy process approach for ranking of effective material selection criteria. Advances in Materials Science and Engineering 2015:2015:845346. 
[53] Vidal LA, Marle F, Bocquet JC. Using a Delphi process and the Analytic Hierarchy Process (AHP) to evaluate the complexity of projects. Expert Systems with Applications 2011:38:5388-5405.

[54] Kharat MG, Raut RD, Kamble SS, Kamble SJ. The application of Delphi and AHP method in environmentally conscious solid waste treatment and disposal technology selection. Management of Environmental Quality: An International Journal 2016:27:427-440.

[55] Kwok PK, Lau HY. Modified Delphi-AHP method based on minimum-cost consensus model and vague set theory for road junction control method evaluation criteria selection. Journal of Industrial and Intelligent Information 2016:4:76-82.

[56] KianiSadr M, Melhosseini Darani K, Golkarian H. Quantitative zoning of ecotourism potential in Oshtorankouh protected area using Delphi method, analytic hierarchy process, and weighted overlay methods. Ecopersia 2019:7:115-123.

[57] Çolak M, Kaya İ. Multi-criteria evaluation of energy storage technologies based on hesitant fuzzy information: A case study for Turkey. Journal of Energy Storage 2020:28:101211.

[58] Etebarian A, Shirvani A, Soltani I, Moradi A. Applying fuzzy Delphi method and fuzzy analytic hierarchy process for ranking marine casualties. Proceedings of the 2014 International Conference on Neural Networks-Fuzzy Systems 2014:135-146.

[59] Saaty TL. the Analytic Hierarchy Process. McGraw-Hill, New York, 1980.

[60] Karapetrovic S, Rosenbloom ES. A quality control approach to consistency paradoxes in AHP. European Journal of Operational Research 1999:119:704-718.

[61] Wedley WC. Consistency prediction for incomplete AHP matrices. Mathematical and Computer Modelling 1993:17:151-161.

[62] Lane EF, Verdini WA. A consistency test for AHP decision makers. Decision Sciences 1989:20:575-590.

[63] Ahmed F, Al Amin AQ, Hasanuzzaman M, Saidur R. Alternative energy resources in Bangladesh and future prospect. Renewable and Sustainable Energy Reviews 2013:25:698-707.

[64] Halder PK, Paul N, Joardder MU, Sarker M. Energy scarcity and potential of renewable energy in Bangladesh. Renewable and Sustainable Energy Reviews 2015:51:1636-1649.

[65] Islam MT, Shahir SA, Uddin TI, Saifullah AZ. Current energy scenario and future prospect of renewable energy in Bangladesh. Renewable and Sustainable Energy Reviews 2014:39:1074-1088.

[66] Hossain MF, Hossain S, Uddin MJ. Renewable energy: Prospects and trends in Bangladesh. Renewable and Sustainable Energy Reviews 2017:70:44-49.

[67] Flood Hazard Research Centre. NMT Computer. 2010. Available: http://www.fhrcbd.org/views/physicalgeography.php.

[68] Khan SH, Rahman T, Hossain S. A brief study of the prospect of solar energy in generation of electricity in Bangladesh. Journal of Selected Areas in Renewable and Sustainable Energy 2012:1-8.

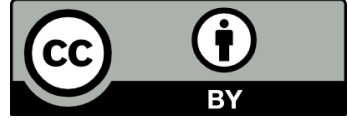

(C) The Author(s) 2020. This article is published under a Creative Commons Attribution (CC-BY) 4.0 International License. 